\title{
Water erosion estimate in Belem Stream Watershed in Minas Gerais state
}

\author{
Guilherme Henrique Expedito Lense ${ }^{1 *}$, Fernanda Almeida Bócoli², Rodrigo Santos Moreira ${ }^{3}$, Ronaldo Luiz \\ Mincato ${ }^{4}$
}

\begin{abstract}
Water erosion causes a diversity of negative environmental impacts, provoking soil degradation and by consequence the agricole production decrease. Due to the damage caused by the soil erosion process, were developed a diversity of water erosion modeling methods in other to support in other to project and implement measures soil conservation. Among the models, the more useful is the Erosion Potential Method (EPM), which recently was adapted to the brazilian tropical conditions. In this context, the objective of this work was estimating the soil loss by Erosion Potential Method in a water basin located in Muzambinho, in the South of Minas Gerais. The EPM model estimated the water erosion in this study area starting with climate, topographic, pedology, land use, and erosive features degree parameters. The modeling stage and the parameters obtaining was done with the Geography Information System and remote sensing help. The total soil loss estimated by the EPM model was 10,418.53 $\mathrm{Mg}_{\text {year }}{ }^{1}$, of which $5.50 \%$ reaches the water resources directly contributing to the siltation and water quality depreciation. The higher slope areas and the rural roads with exposed soil are where localize the biggest soil loss degrees. The modeling application was giving up in a simple and fast form, provender satisfactory results that are useful to the planning of soil conservation practices in the water basin.
\end{abstract}

Keys words: Soil conservation. Erosion Potential Method. Agricole Sustainability.

\section{Estimativa da erosão hídrica na Bacia Hidrográfica do Córrego Belém, Minas Gerais}

\begin{abstract}
Resumo
A erosão hídrica gera diversos impactos negativos ao ambiente provocando a degradação do solo e consequente queda da produção agrícola. Devido aos danos causados pelo processo, foram desenvolvidos diversos métodos de modelagem da erosão hídrica afim de auxiliar na projeção e implementação de medidas de conservação do solo. Dentre os modelos têm se o Método de erosão potencial (EPM) que recentemente foi adaptado para as condições tropicais brasileiras. Nesse contexto, o objetivo do trabalho foi estimar as perdas de solo pelo Método de Erosão Potencial em uma bacia hidrográfica situada em Muzambinho no Sul de Minas Gerais. O modelo EPM estimou a erosão hídrica na área a partir de parâmetros referentes ao clima, topografia, pedologia, uso da terra e grau das feições erosivas. As etapas da modelagem e a obtenção dos parâmetros foram feitas com auxílio de Sistema de Informação Geográfica e sensoriamento remoto. O modelo EPM estimou a perda de solo total em 10.418,53 $\mathrm{Mg}_{\text {ano-1 }}$, das quais $5,50 \%$ atingem diretamente os cursos hídricos contribuindo para o assoreamento e depreciação da qualidade da água. As áreas com maior declividade, e as estradas rurais com presença de solo exposto são onde se concentraram as maiores taxas de perda de solo. A aplicação do modelo se deu de forma rápida e simples, fornecendo resultados satisfatórios que são uteis para o planejamento da adoção de práticas de conservação do solo na bacia hidrográfica.
\end{abstract}

Palavras chave: Conservação do solo. Método de Erosão Potencial. Sustentabilidade agrícola.

${ }^{1}$ Universidade Federal de Alfenas. Alfenas, MG. Brasil.

https://orcid.org/0000-0002-3560-9241

${ }^{2}$ Universidade Federal de Lavras. Lavras, MG. Brasil.

https://orcid.org/0000-0001-5476-6886

${ }^{3}$ Universidade Federal de Alfenas. Alfenas, MG. Brasil.

https://orcid.org/0000-0001-7443-94

${ }^{4}$ Universidade Federal de Alfenas. Alfenas, MG. Brasil.

https://orcid.org/0000-0001-8127-0325

*Autor para correspondência: guilhermeelense@gmail.com

Recebido para publicação em 18 de novembro de 2019. Aceito para publicação em 27 de março de 2020.

e-ISSN: 2447-6218 / ISSN: 2447-6218 / (C) 2009, Universidade Federal de Minas Gerais, Todos os direitos reservados. 


\section{Introduction}

Water erosion occurs in the worldwide watershed, with strong anthropic influences. In advanced stages, this phenomenon provokes soil loss, removes nutrients, organic carbon and agrochemicals out of the systems, diminishing the agricole production (Avanzi et al., 2013). This kind of erosion also generates the sediment deposition in hydric courses promoting the siltation and with it the water quality decrease (Haghizadeh; Shui; Godarzi, 2009).

Given the various negative impacts generated by the erosion, the estimative of damage scope is essential, in other to project and implement targeted and effective measures soil conservation. In this way, was developed a model diversity that simulates soil loss, as the Erosion Potential Method (EPM). The EPM is an empiric model, of easy utilization, implementation capacity with Geography Information System (GIS) and application low cost (Efthimiou et al., 2017). The EPM is the largest applied to identification of the high vulnerability areas to erosive process, and recently this method was adapted to brazilian tropic conditions (Efthimiou et al., 2017; Lense et al., 2019; Sakuno et al. 2020; Tavares et al., 2019).
In this context, the objective of this work was estimating the soil loss by Erosion Potential Method in a watershed located in Muzambinho, in the South of Minas Gerais, in other to subsidiary the planning of conservationist practices.

\section{Material and Methods}

\section{Study area}

The study area corresponds to the Belem Stream Watershed, Muzambinho river affluent, situated in Muzambinho city, Minas Gerais South region, Brazil (Figure 1) (from $46^{\circ} 32$ ' $44^{\prime \prime}$ to $46^{\circ} 34^{\prime} 35^{\prime \prime} \mathrm{W}$ and $21^{\circ} 24^{\prime} 7^{\prime \prime}$ to $21^{\circ} 26^{\prime} 32^{\prime \prime}$ S, SIRGAS 2000). The basin presents an area of 997,75 ha, with altitudes varying from $1020 \mathrm{~m}$ to $1240 \mathrm{~m}$ (Figure 1A). The region climate second Köppen classification is Mesothermal Tropical (Cwb) (Alvares et al., 2013), with wavy relief (8 - 20\%) predominantly (Figure 1B) and soils classified as Red Dystrophic Latosols (UFV, 2010).

Figure 1 - Localization, Digital Elevation Model (A) and Declivity Map (B) of Belem Stream Watershed, Muzambinho, South of Minas Gerais, Brazil.

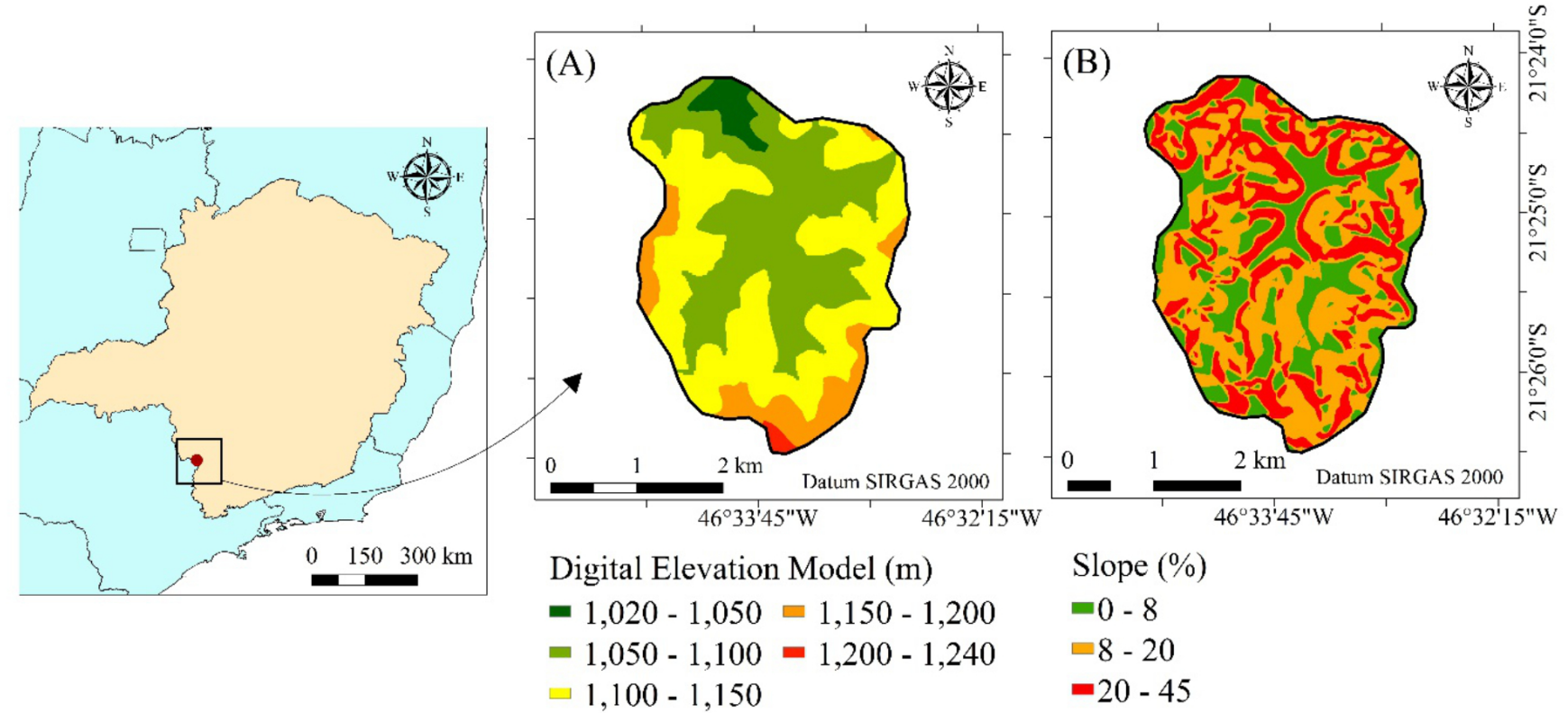

The Digital Elevation Model (DEM) was elaborated from Brazil in Relief digital platform available data (Miranda, 2005). With DEM utilization was elaborated the Declivity Map (spatial resolution of 10 meters), by the Slope tool from ArcMap 10.3 (ESRI, 2015).

The predominant crop in the area is coffee (39.62\%), followed by degraded pasture (32.07\%), native forest $(24.05 \%)$, rural roads $(1.20 \%)$, facilities $(0.51 \%)$ and drainage $(2.55 \%)$. The land use map (Figure 2) was done basing in field survey, images from Google Earth (2019) and of Landsat-8 Operational Land Imager (OLI) satellite, bands 2, 3 e 4, in the orbit 219, point 75, obtained of Images Division Generation (INPE, 2019). It was used the ArcMap 10.3 (ESRI, 2015) software. 
Figure 2 - Land use map of Belem Stream Watershed, Muzambinho, south of Minas Gerais, Brazil.

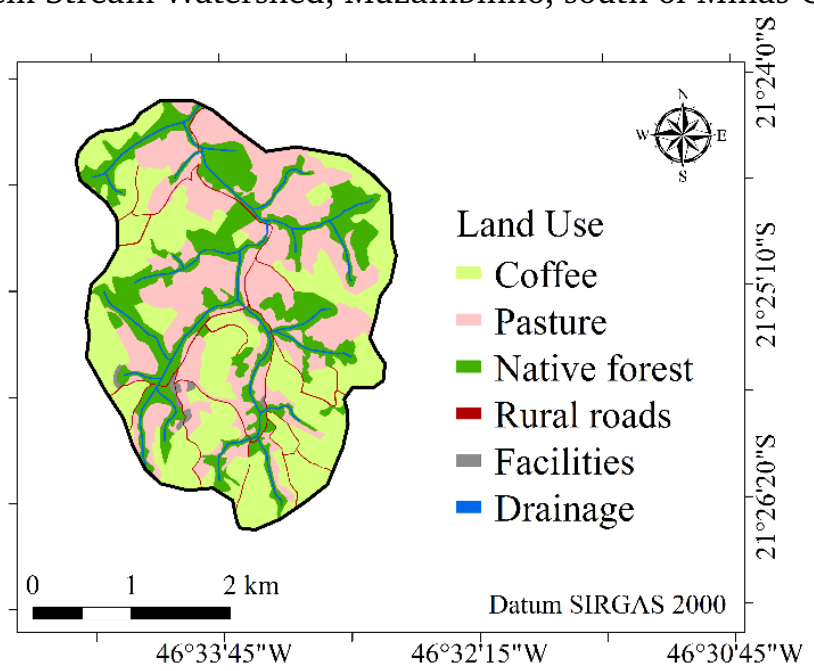

\section{Erosion Potential Method}

The EPM model estimates the water erosion from climate, topographic, pedology, land use, and erosion feature degree. The area erosive process susceptibility to (Z) is calculated as Equation 1. Areas with $\mathrm{Z}>1.0$ values present high susceptibility to erosion, while areas with Z $<0.19$ present low susceptibility to erosion (Gavrilovic, 1962).

$$
\mathrm{Z}=\mathrm{Y} \cdot \mathrm{X}_{\mathrm{a}} \cdot\left(\varphi+\sqrt[2]{\mathrm{I}_{\mathrm{sr}}}\right) \text { Equation } 1
$$

On what, $\mathrm{Y}=$ water erosion soil resistance; $\mathrm{X}_{\mathrm{a}}=$ coefficient of soil use and management; $\varphi=$ coefficient of visible erosion features, both dimensionless and $\mathrm{I}_{\mathrm{sr}}=$ mean slope in $\%$.
The parameter $Y$ varies from 0.25 to 2 and represents the soil resistance to the erosive process, whereas the higher the $\mathrm{Y}$ value lower is the hydric erosion soil resistance. The $\mathrm{X}_{\mathrm{a}}$ varies from 0.05 to 1 , according to the ground cover, on what exposed soils present the biggest $\mathrm{X}_{\mathrm{a}}$ values. As for the parameter $\varphi$, it varies from 0.1 to 1 and is visually determinate according to erosive features present in the study area. The parameters $\mathrm{Y}, \mathrm{X}_{\mathrm{a}}$ and $\varphi$ are calculated using Gavrilovic (1962) tabled values, adapted by Sakuno et al. (2020) to Brazilian conditions. The area means slope $\left(\mathrm{I}_{\mathrm{sr}}\right)$ is $8.40 \%$, calculated using the slope map (Figure 1B).

Utilizing the coefficient $Z$, the EPM estimates the total soil loss $\left(\mathrm{W}_{\mathrm{yr}}\right)$ in $\mathrm{Mg}$ year ${ }^{-1}$, according to Equation 2:

$$
\mathrm{W}_{\mathrm{yr}}=\left(\sqrt[2]{\frac{\mathrm{t}_{0}}{10}}+0.1\right) \cdot \mathrm{H}_{\mathrm{yr}} \cdot \pi \cdot \sqrt[2]{\mathrm{Z}^{3}} \cdot \mathrm{Ds} \cdot \mathrm{F} \text { Equation } 2
$$

On what: $\mathrm{t}_{0}=$ mean air temperature in ${ }^{\circ} \mathrm{C}$ year ${ }^{1} ; \mathrm{H}_{\mathrm{yr}}=$ annual average rainfall, in mm; Ds = mean soil density in $\mathrm{kg} \mathrm{dm}^{-3} ; \mathrm{F}=\mathrm{study}^{\mathrm{area}}\left(\mathrm{km}^{2}\right)$.

For the study area, the $\mathrm{t}_{0}$ and the $\mathrm{H}_{\mathrm{yr}}$ were $19^{\circ} \mathrm{C}$ and $1500 \mathrm{~mm}$, respectively. The climate data was obtained basing in a weather station next to the study area. For the soil mean density has utilized the value of 1.21 $\mathrm{kg} \mathrm{dm}^{-3}$, obtained by Lense et al. (2019), also in the south of Minas Gerais.

The EPM allows estimating the eroded soil fraction that is retained in the water basin interior and the fraction that reaches hydrous bodies by the Retention Coefficient $\left(\mathrm{R}_{\mathrm{u}}\right)$ utilization, calculated as Zemljic (1971) (Equation 3).

$$
\mathrm{R}_{\mathrm{u}}=\frac{(\mathrm{O} \cdot \mathrm{D})^{0,5} \cdot(\mathrm{L}+\mathrm{Li})}{\mathrm{F} \cdot(\mathrm{L}+10)} \text { Equation } 3
$$

On what: $\mathrm{F}=$ watershed area $\left(9.97 \mathrm{~km}^{2}\right) ; \mathrm{O}=$ perimeter $(12.99 \mathrm{~km})$; $\mathrm{D}=$ mean elevation difference $(0.09 \mathrm{~km})$, obtained by the difference between the mean altitude $(1108 \mathrm{~m})$ and the minimum altitude $(1020 \mathrm{~m}) ; \mathrm{L}=$ water basin main length $(4.40 \mathrm{~km})$ and $\mathrm{Li}=$ secondary length $(2.85 \mathrm{~km})$.
The modeling stages and the parameter obtention was done with the GIS and remote sensing help utilizing ArcMap 10.3 (ESRI, 2015) software.

\section{Results and Discussion}

The $\mathrm{Y}$ value to the hydrographic basin Latosols was 0.8 , indicating good resistence to the erosive process. The vegetation cover of the area provided high soil protection, especially in the forest and coffee growing areas with an average $X_{a}$ of 0.40 . The average $\varphi$ value of the area is 0.32 , with laminar erosion occurring predominantly in crops, while on rural roads erosion in furrows predominates. Based on these parameters and the slope of the area, the erosion intensity coefficient (Z) was quantified at 0.22 , indicating that the vast majority of the watershed has low susceptibility to water erosion. 
The total soil loss estimated by the EPM model was $10,418.53 \mathrm{Mg}$ year $^{-1}$, of which $5.50 \%$ (Retention Coefficient value $-\mathrm{R}_{\mathrm{u}}$ ) reaching directly the hydric courses contributing to siltation and water quality depreciation. The higher slope areas and the rural roads with exposed soil are where localize the biggest soil loss degrees (Fi- gure 3). According to Pandey et al. (2007) and Beskow et al. (2009), erosive rates lower than $4 \mathrm{Mg}$ year $^{-1}$ and higher than $15 \mathrm{Mg}$ year $^{-1}$ can be considered of low and high intensity respectively. In this contest, $27 \%$ of the hydrographic basin, has a small soil loss and $25 \%$ of the area has an elevated one.

Figure 3 - Soil loss estimates of Potential Erosion Method in the Belem Stream watershed, Muzambinho, south of Minas Gerais, Brazil.

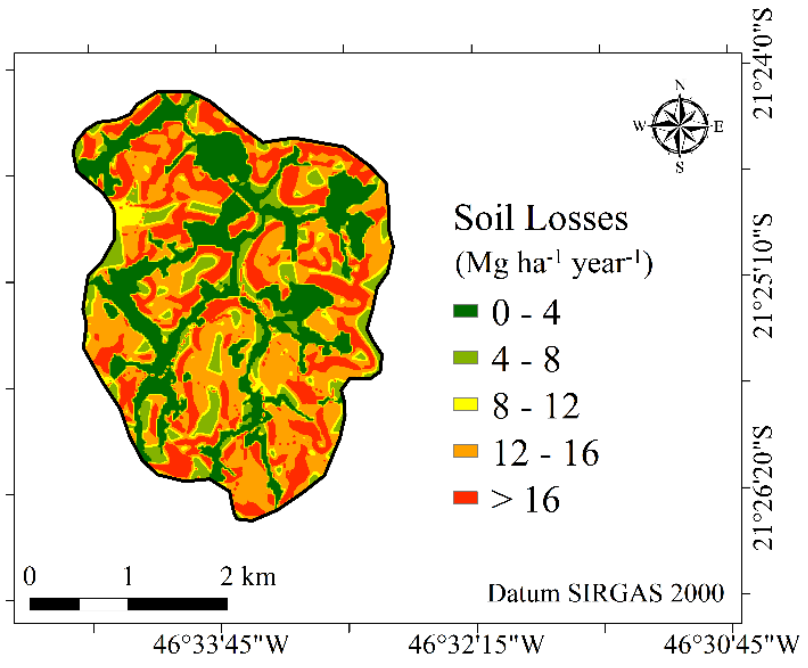

The high soil loss areas, observed in Figure 3, might be prioritized in the erosion mitigation measures introduction, and, as these areas are distributed in the whole hydrographic basin is necessary a broad planning of conservationist practices introduction (Beskow et al., 2009).

Considering the land use classes, the lower erosive rates were observed in the forest areas $(1.85 \mathrm{Mg}$ ha $^{-1}$ year $^{-1}$ ), followed by coffee (13.50 $\mathrm{Mg} \mathrm{ha}^{-1}$ year $\left.{ }^{-1}\right)$, pasture (14.00 $\mathrm{Mg} \mathrm{ha}^{-1}$ year $^{-1}$ ) and access roads (16.10 $\mathrm{Mg} \mathrm{ha}{ }^{-1}$ year $^{-1}$ ). The native forest vegetation elevated density promoted lower soil loss rates on this land use, a result similar to Lense et al (2019) and Tavares et al (2019). The areas with facilities and hydric courses weren't considered in EPM calculation because they do not participate in sediment generation.

To reduce the hydric erosion there should be introduced measures to diminish the agricole activities' impact over the soil, improving the soil covering and consequently the soil protection. The degraded pasture areas have to pass to a vegetation recovering process and the coffee cultivation area, conservationists' practices, as the vegetation management between coffee rows, has to be maximized in other to reduce the erosion to minimum rates. As the rural roads, the introduction of gravel and containment basins are alternatives in other to reduce the groove erosion (Scharrón; Sánchez, 2017; Lense et al., 2019).

\section{Conclusion}

The Erosion Potential Method estimated the Belem Stream hydrographic basin soil loss in $10,418.53$ $\mathrm{Mg}$ year ${ }^{-1}$. About $5.50 \%$ of eroded soil reach directly the area hydric courses.

The modeling application was giving up in a simple and fast form, provender satisfactory results that are useful to the planning of soil conservation practices in the water basin.

\section{Acknowledgments}

The authors thank the Fundação de Amparo à Pesquisa do Estado de Minas Gerais (FAPEMIG) for the scholarship offered to the first author.

This study was financed in part by the Coordenação de Aperfeiçoamento de Pessoal de Nível Superior - Brasil (CAPES) - Finance Code 001.

\section{References}

Alvares, C. A.; Stape, J. L.; Sentelhas, P. C.; Gonçalves, J. L. M.; Sparovek, G. 2013. Köppen's climate classification map for Brazil. Meteorologische Zeitschrift, 22:711-728. https://doi.org/10.1127/09412948/2013/0507.
Avanzi, J. C.; Silva, M. L. N.; Curi, N.; Norton, L. D.; Beskow, S.; Martins, S. G. 2013. Spatial distribution of water erosion risk in a watershed with eucalyptus and Atlantic Forest. Ciência e Agrotecnologia, 37:427 434. https://doi.org/10.1590/S1413-70542013000500006. 
Water erosion estimate in Belem Stream Watershed in Minas Gerais state

Beskow, S.; Mello, C. R.; Norton, L. D.; Curi, N.; Viola, M. R.; Avanzi, J. C. 2009. Soil erosion prediction in the Grande River Basin, Brazil using distributed modeling. Catena, 79:49-59. https://doi.org/10.1016/j. catena.2009.05.010.

Efthimiou, N.; Lykoudi, E.; Karavitis, C. 2017. Comparative analysis of sediment yield estimations using different empirical soil erosion models. Hydrological Sciences Journal, 62:2674-2694. https://doi. org/10.1080/02626667.2017.1404068.

Environmental Systems Research Institute - ESRI. 2015. ARCGIS Professional GIS for the desktop version 10.3. Redlands, Califórnia, EUA, Software.

Gavrilovic, S. 1962. A method for estimating the average annual quantity of sediments according to the potency of erosion. Bulletin of the Faculty of Forestry, 26:151-168.

Google. Google Earth. Version 7.3.2.5776. 2019. Available in: http:// www.google.com.br/earth/download/gep/agree.html.

Haghizadeh, A.; Shui, L. T.; Godarzi, E. 2009. Forecasting Sediment with Erosion Potential Method with Emphasis on Land Use Changes at Basin. Electronic Journal of Geotechnical Engineering, 14: 1-12.

Instituto Nacional de Pesquisas Espaciais - INPE. 2019. SGI 2.5 Divisão de Geração de Imagens (DIDGI). SGI. Imagem Geosistemas, São José dos Campos: Instituto Nacional de Pesquisas Espaciais. Available in: http://www.dgi.inpe.br/CDSR/.

Lense, G. H. E; Parreiras, T. C.; Moreira, R. S.; Avanzi, J. C.; Mincato, R. L. 2019. Estimates of soil losses by the erosion potential method in tropical latosols. Ciência e Agrotecnologia, 43:e012719. https:// dx.doi.org/10.1590/1413-7054201943012719.
Miranda, E. E. 2005. Brasil em Relevo. Campinas: Embrapa Monitoramento por Satélite. Available in: http://www.relevobr.cnpm. embrapa.br.

Pandey, A.; Chowdary, V. M.; Mal, B. C. 2007. Identification of critical erosion prone areas in the small agricultural watershed using USLE, GIS and remote sensing. Water Resources Management, 21:729-746. https://doi.org/10.1007/s11269-006-9061-z.

Sakuno, N. R. R.; Guiçardi, A. C. F.; Spalevic, V.; Avanzi, J. C.; Silva, M. L. N.; Mincato, R. L. 2020 Adaptation and application of the erosion potential method for tropical soils. Revista Ciência Agronômica, 51:e20186545. https://dx.doi.org/10.5935/1806-6690.20200004.

Scharrón, C. E. R.; Sánchez, Y. F. 2017. Plot-, farm-, and watershedscale effects of coffee cultivation in runoff and sediment production in western Puerto Rico. Journal of Environmental Management, 202:126-136. https://doi.org/10.1016/j.jenvman.2017.07.020.

Tavares, A. S.; Spalevic, V.; Avanzi, J. C.; Nogueira, D. A.; Silva, M. L. N.; Mincato, R. L. 2019. Modeling of water erosion by the erosion potential method in a pilot subbasin in southern Minas Gerais. Semin-Ciencias Agrárias, 40:555-572. https://doi.org/10.5433/16790359.2019v40n2p555.

Universidade Federal de Viçosa - UFV. 2010. Mapa de solos de Minas Gerais: legenda expandida. (1:650.000). Belo Horizonte: Fundação Estadual do Meio Ambiente / UFV / CETEC / UFLA / FEAM. Available in: http://www.dps.ufv.br/?page_id=742.

Zemljic, M. 1971. Calculation of sediment load. Evaluation of vegetation as anti-erosive factor. In: Proceedings of the international symposium Interpraevent, p.379-391. 